\title{
Two cases of mild IgM-negative measles in previously vaccinated adults, the Netherlands, April and July 2011
}

A van den Hoek (avdhoek@ggd.amsterdam.nl) ${ }^{1,2}$, G J Sonder ${ }^{1,2}$, M Scholing $^{1,3}$, DB Gijselaar ${ }^{4}$, R S van Binnendijk ${ }^{4}$

1. Public Health Service Amsterdam, the Netherlands

2. Academic Medical Centre, Amsterdam, the Netherlands

3. Onze Lieve Vrouw Gasthuis, Amsterdam, the Netherlands

4. Rijksinstituut voor Volksgezondheid en Milieu (RIVM; National Institute for Public Health and the Environment), Bilthoven, the Netherlands

Citation style for this article:

van den Hoek A, Sonder GJ, Scholing M, Gijselaar D, van Binnendijk RS. Two cases of mild IgM-negative measles in previously vaccinated adults, the Netherlands, April and July 2011.

Euro Surveill. 2011;16(48):pii=20028. Available online: http://www.eurosurveillance.org/ViewArticle.aspx?Articleld=20028

Article published on 1 December 2011

We describe two cases of mild, modified measles in fully vaccinated adults in the Netherlands. The mildness of disease, the lack of an IgM antibody response, the relatively low amounts of virus detected and the fact that no additional cases were reported, suggests that these vaccinated patients were less contagious than unvaccinated patients.
We report here two cases of measles in persons who had received two doses of measles vaccine according to the recommended schedule. They were investigated in the context of two measles clusters that occurred in the Netherlands in April and June-July 2011.The characteristics of these clusters are summarised in the Table.

\section{TABLE}

Characteristics of patients in two clusters of measles, Amsterdam, the Netherlands, April-July $2011(\mathrm{n}=6)$

\begin{tabular}{|c|c|c|c|c|c|c|c|c|c|c|}
\hline Cluster & Case & $\begin{array}{l}\text { Year of } \\
\text { birth }\end{array}$ & $\begin{array}{l}\text { Disease } \\
\text { onset } \\
(2011)\end{array}$ & $\begin{array}{c}\text { Source } \\
\text { of } \\
\text { infection }\end{array}$ & Transmission & $\begin{array}{c}\text { Measles } \\
\text { vaccination } \\
\text { history } \\
\text { (reason) }\end{array}$ & $\begin{array}{c}\lg M \\
\text { serology }\end{array}$ & $\begin{array}{l}\text { IgG serology } \\
(\mathrm{mIU} / \mathrm{ml})\end{array}$ & Realtime $P C R^{a}$ & $\begin{array}{c}\text { World Health } \\
\text { Organization } \\
\text { definition } \\
\text { (genotype) }^{\mathrm{b}}\end{array}$ \\
\hline 1 & A & After 1987 & $3 \mathrm{Apr}$ & France & Unknown & $\begin{array}{l}\text { No (critical } \\
\text { attitude) }\end{array}$ & Positive & Not sampled & $\begin{array}{l}\text { Throat/urine } \\
\text { positive: day } 9 \\
(\Delta C T \text { 8.4/6.2) }\end{array}$ & $\begin{array}{l}\text { MVs/Amsterdam. } \\
\text { NLD/ 15.11/1[D4] }\end{array}$ \\
\hline 1 & B & $\begin{array}{c}\text { Between } \\
1976 \text { and } \\
1987 \\
\end{array}$ & $18 \mathrm{Apr}$ & $\begin{array}{l}\text { Sports } \\
\text { club }\end{array}$ & $\begin{array}{c}\text { Contact of } \\
1 \mathrm{~A}\end{array}$ & $2 x$ & Negative & $\begin{array}{c}6,000 / 140,000 \\
\text { (day o/22) }\end{array}$ & $\begin{array}{l}\text { Throat/urine } \\
\text { positive: day o } \\
(\Delta C T \text { 11.2/7.9) }\end{array}$ & $\begin{array}{l}\text { MVs/Amsterdam. } \\
\text { NLD/ 15.11/2[D4] }\end{array}$ \\
\hline & & & & & & & & & & \\
\hline 2 & A & $\begin{array}{c}\text { Between } \\
1970 \text { and } \\
1976 \\
\end{array}$ & 26 June & Spain & Unknown & No (age) & Positive & Not sampled & $\begin{array}{l}\text { Urine positive: } \\
\text { day } 11\left(\Delta C T_{7.2}\right)\end{array}$ & $\begin{array}{l}\text { MVs/Amsterdam. } \\
\text { NLD/ 27.11/1[D4] }\end{array}$ \\
\hline 2 & B & $\begin{array}{l}\text { Under } 12 \\
\text { months- } \\
\text { old }\end{array}$ & 4 July & Spain & $\begin{array}{l}\text { Contact of } \\
2 \mathrm{~A} \text { (child) }\end{array}$ & No (age) & $\begin{array}{l}\text { Not } \\
\text { tested }\end{array}$ & Not sampled & $\begin{array}{c}\text { Oral fluid } \\
\text { positive: day } 3 \\
(\Delta C T \text { 12.5) }\end{array}$ & $\begin{array}{l}\text { MVs/Amsterdam. } \\
\text { NLD/ 27.11/2[D4 }]^{d}\end{array}$ \\
\hline 2 & $\mathrm{C}$ & $\begin{array}{l}\text { Between } \\
1970 \text { and } \\
1976\end{array}$ & 9 July & Hospital & $\begin{array}{l}\text { Contact of } \\
2 \mathrm{~A} \text { (nurse) }\end{array}$ & No (age) & $\begin{array}{l}\text { Not } \\
\text { tested }\end{array}$ & Not sampled & $\begin{array}{l}\text { Throat/urine } \\
\text { positive: day } 6 \\
(\Delta C T \text { 9.1/10.3) }\end{array}$ & $\begin{array}{l}\text { MVs/Amsterdam. } \\
\text { NLD/ 28.11/1[D4 }]^{d}\end{array}$ \\
\hline 2 & D & $\begin{array}{c}\text { Between } \\
1976 \text { and } \\
1987\end{array}$ & 9 July & Hospital & $\begin{array}{c}\text { Contact } \\
\text { of } 2 \mathrm{~A} \\
\text { (physician) }\end{array}$ & $2 x$ & Negative & $\begin{array}{c}18,000 / 36,000 \\
(\text { day } 5 / 38)\end{array}$ & $\begin{array}{l}\text { Urine negative, } \\
\text { throat positive: } \\
\text { day } 5\left(\Delta \mathrm{CT} 2.5 / \text {--) }^{-}\right.\end{array}$ & $\begin{array}{l}\text { MVs/Amsterdam. } \\
\text { NLD/ 28.11/1[D4 }]^{\mathrm{d}}\end{array}$ \\
\hline
\end{tabular}

Measles RNA content of each individual specimen is expressed here quantitatively as a difference operator ( $\triangle C T)$, which refers to the difference between the cycle threshold) (CT) value of the clinical specimen and the CT value of the lowest amount of measles RNA that is detectable in the realtime PCR assay.

b Genotype analysis is based on the $456 \mathrm{bp} \mathrm{N}$-terminal part of the measles virus nucleoprotein $(\mathrm{N})$ gene.

$100 \%$ identity with genotype submissions from e.g. France, the United Kingdom and Germany in 2010 (Genbank accession numbers: FR671429, HQ202158, HQ704333, respectively).

d All four cases in the second cluster had identical D4 sequences, which differed from Cluster 1 by one nucleotide; no exact match was found in Genbank nor in the Measles Nucleotide Surveillance (MeaNS) database. 


\section{Case 1B}

The first case was a patient born between 1976 and 1987 (Table, Case 1B) with a verified history of two vaccinations. The patient developed fever and exanthema on 18 April 2011, with no complaints of coughing, coryza or conjunctivitis and without Koplik spots. The exanthema was typical for measles. Blood samples taken on the same day and tested by Serion Elisa classic Measles Virus IgG/IgM showed an IgM concentration of $7 \mathrm{mIU} / \mathrm{ml}$ (negative) and an IgG concentration of $>5,000 \mathrm{mIU} / \mathrm{ml}$ (positive). PCR tests on urine and saliva were positive for measles virus. We repeated the blood tests on 10 May: the IgM test remained negative ( $<5$ $\mathrm{mIU} / \mathrm{ml}$ ) and the IgG titre remained at $>5,000 \mathrm{mIU} / \mathrm{ml}$. A dilution experiment with paired serum samples from Serion Immundiagnostica $\mathrm{GmbH}$ showed a more than four-fold increase in IgG titre (from 6,000 to 140,000 $\mathrm{mIU} / \mathrm{ml}$ ). The negative IgM results were confirmed by another reference IgM assay (Enzygnost EIA) which returned values of 0.10 (indeterminate) and 0.15 (indeterminate) for the two consecutive samples. The latter assay was repeated and returned IgM values of 0.09 (negative) and 0.15 (indeterminate).

The source of this infection was an adult contact in a sports club born after introduction of MMR vaccination in 1987 (Table, Case $1 \mathrm{~A}$ ), who had recently suffered from confirmed measles (IgM- and PCR-positive). This source patient was reported to us in the beginning of April 2011. This person did not have a history of vaccination and had travelled during the incubation period in France, where measles outbreaks are ongoing since 2008 [1].

Genotype analysis of the measles RNA detected in urine and saliva of both patients demonstrated the presence of genotype $D_{4}$ measles virus. This is a highly prevalent genotype found in many European countries in 2010 and 2011, but the epidemiological data corroborates France as the origin of this measles cluster (Table, Cluster 1). In 2011 other genotype D4 measles cases were reported in the Netherlands, some of which had identical D4 sequences, but neither of which could be epidemiologically linked to the two cases of this first cluster (data not shown).

\section{Case 2D}

The second case was a physician, born between 1976 and 1987, who also had a verified history of two measles vaccinations (Table, Case 2D). The physician developed a rash typical of measles on 9 July 2011 and did not complain of fever, coryza, coughing or conjunctivitis. A blood test on14 July was negative for IgM $(6 \mathrm{mIU} / \mathrm{ml})$ and positive for IgG $(>5,000 \mathrm{mlU} / \mathrm{ml})$. Virus was detected by PCR in a nasopharyngeal sample taken on 19 July. The results of blood tests taken on 16 August were negative for IgM and had an IgG titre of $>5000 \mathrm{mIU} / \mathrm{ml}$. A dilution experiment with paired serum samples by Serion Immundiagnostica $\mathrm{GmbH}$ showed a less than fourfold increase in IgG titre (from 18,000 to $36,000 \mathrm{mIU} / \mathrm{ml}$ ), and again IgM results were confirmed negative by a another reference IgM assay (Enzygnost EIA) which returned IgM values of 0.09 and 0.05 for the two consecutive samples.

The source of Case 2D's infection was a patient, born in between 1970 and 1976 (Case 2A), who did not have a history of measles vaccination and who had travelled to Spain during the incubation period. The patient attended an emergency department where the physician was working on 26 and 27 June 2011, with complaints of fever and rash. The measles diagnosis was confirmed with a positive IgM test and virus detection by PCR in a urine sample (Table, Case $2 \mathrm{~A}$ ).

Besides the physician, the source patient also infected a nurse born between 1970 and 1976, without a history of measles vaccination (Table, Case $2 \mathrm{C}$ ), and the source patients' 10 month-old child (Table, Case 2B). In all four patients, genotype analysis demonstrated the presence of a similar genotype D4 measles virus RNA as documented in the first cluster, which differed from the first cluster by one nucleotide (Table). This nucleotide change was present in all four cases but did not match any of the currently documented D4 strains in Genbank or the Measles Nucleotide Surveillance (MeaNS) database (http://www.who-measles.org). In the time period, when cluster 2 was occurring, three other genotype D4 cases were reported in the Netherlands, but none of these were epidemiologically or molecularly linked to Cluster 2 (data not shown).

In the Netherlands, childhood measles vaccination has been ongoing since 1976. Since 1987, two doses of measles, mumps and rubella (MMR) vaccine have been recommended for children aged 14 months and nine years. The coverage of both doses has been consistently high (>95\%) in the last decades [2], but is not even throughout the country. About $1-2 \%$ of the population refuse vaccination on religious grounds. The last outbreak of measles in these religious communities was from April 1999 to May 2000 and consisted of at least 3,292 reported cases, including three deaths [3]. No major outbreaks have been observed since, except for a restricted outbreak in an anthroposophic community in 2008 [4]. Since 2009 large outbreaks of measles have been reported in various European countries. The same virus genotype (D4) is responsible for most of these outbreaks [1]. In the Netherlands, no major outbreaks have been seen apart from some small clusters of patients. The majority of the index cases acquired their disease outside the Netherlands.

\section{Conclusions}

Our data show that fully vaccinated persons were infected with measles virus, albeit in the absence of IgM seroconversion. Variable results with respect to IgM antibody detection in infected persons who had been fully vaccinated against measles have been presented before [5-7]. Our two cases developed rash and some fever, but no other specific symptoms. Due to resurgence of measles in Europe, we anticipated an increase 
in measles importations in the Netherlands, which is why suspected cases were more often investigated. Moreover, laboratory diagnostics were extended to include RT-PCR on nasopharyngeal or urine specimens to detect the presence of measles virus, and serological confirmation on paired serum samples.

We conclude that mild measles in previously vaccinated persons due to waning immunity can occur and the IgM test result can remain negative. Case $1 B$ developed a more than four-fold increase in IgG titre, which, as shown here, strongly depends on early blood sampling. The high IgG titres in case $2 \mathrm{D}$ also indicate a strong secondary antibody response.

We preferred measles virus RNA detection by RT-PCR in urine and oropharyngeal samples because this was found to be the most conclusive diagnostic method and also allows epidemiological linkage between the cases using genotyping. On the basis of both molecular data and travel history, the source of these small clusters of measles was found to be unvaccinated adults who had most likely imported measles virus from outside the Netherlands. It should be noted that we do not know the extent of virus transmission other than for the clinical cases presented here. However, surveillance of contacts of the two mild cases did not identify additional cases, which is consistent with findings in other recently published case studies [5]. Given the mild disease in these patients, the lack of a systemic IgM antibody response, and reduced shedding of measles virus estimated by realtime PCR, these vaccinated patients may also have been less contagious than unvaccinated patients. When taking the time of sampling into account, this is best illustrated for the vaccinated case in Cluster 2 (see Table). However, further studies are clearly needed to generalise such a conclusion.

\section{Acknowledgments}

We thank Frederic Paquet of Serion Immundiagnostica GmbH for his efforts to find a more than fourfold increase in measles IgG titres, Jeroen Cremer and Jeroen Kerkhof for technical assistance and Susan Hahné for critically reading this manuscript.

\section{References}

1. Parent du Châtelet I, Antona D, Freymuth F, Muscat M Halftermeyer-Zhou F, Maine C, et al. Spotlight on measles 2010: update on the ongoing measles outbreak in France, 2008-2010. Euro Surveill. 2010;15(36): pii=19656. Available from: http://www.eurosurveillance.org/ViewArticle. aspx?Articleld $=19656$

2. van Lier EA, Oomen PJ, Oostenbrug MWM, Zwakhals SLN, Drijfhout IH, de Hoogh PAAM, et al. Vaccinatiegraad Rijksvaccinatieprogramma Nederland, verslagjaar 2009. [Vaccination coverage of the Dutch National Childhood Vaccination Programme]. Rapport 210021010/2009. Bilthoven: Rijksinstituut voor Volksgezondheid en Milieu; 2009. Dutch. Available from: http://www.rivm.nl/bibliotheek/ rapporten/210021010.pdf

3. van den Hof S, Conyn-van Spaendonck MAE, van Steenbergen JE. Measles epidemic in The Netherlands, 1999 to 2000. J Infect Dis. 2002;186(10):1483-6.
4. Hahne S, te Wierik MJ, Mollema L, van Velzen E, de Coster E, Swaan C, et al. Measles Outbreak, The Netherlands, 2008. Emerg Infect Dis. 2010;16(3):567-9.

5. Rota JS, Hickman CJ, Sowers SB, Rota PA, Mercader S, Bellini WJ. Two case studies of modified measles in vaccinated physicians exposed to primary measles cases: high risk of infection but low risk of transmission. J Infect Dis. 2011;204 Suppl 1:S559-63.

6. Hickman CJ, Hyde TB, Sowers SB, Mercader S, McGrew M, Williams NJ, et al. Laboratory characterization of measles virus infection in previously vaccinated and unvaccinated individuals. J Infect Dis. 2011;204: Suppl 1:S549-58.

7. Edmonson MB, Addiss DG, McPherson JT, Berg JL, Circo SR, Davis JP. Mild measles and secondary vaccine failure during a sustained outbreak in a highly vaccinated population. JAMA. 1990;263(18):2467-71. 